\title{
The Principle of Sovereignty as the Main Principle of Democracy, between the Political Pluralism and the Electoral System in the Parlamentary Republic of Albania
}

\author{
Dr. Ismail Tafani \\ Head and Lecturer, \\ Department of Legal Sciences, \\ Albanian University, Albania \\ Prof. Asoc. Dr. Darjel Sina \\ Public Commissioner and Lecturer, \\ Albanian University, Albania
}

DOI: https://doi.org/10.36941/ajis-2020-0123

\section{Abstract}

Popular sovereignty is the foundation of the principle of democracy for the existence and functioning of the rule of law. In the Parliamentary Republic of Albania based on political pluralism for nearly three decades, this essential element of the democratic principle seems to be as fragile as the principle itself. The basic concept of the functionality of the rule of law in Albania under the Constitution is the separation and balancing of powers. Although the constitutional provision for the separation and balancing of powers is clear and based on Montesquieu's conception of the development of the principle of democracy and the prohibition of abuse that each of the powers could inflict on each other, the separation and balancing of powers in Albania seems to be impossible. Albania as a country with a culture of not very long political pluralism, instead it comes from a rather long-term mono-party system where the development of the electoral process was more of a holiday than a race. However, the sovereignty of the people enshrined in today's constitution and yesterday's constitution seems more like a slogan than a fundamental principle of constitutional order. In these years of political pluralism between the test of many electoral systems coupled with constitutional and legal changes, the implementation of the principle of popular sovereignty to consolidate the democratic principle remains clearly a utopia for Albanian society. After each election process debates reopen the need for reforming the electoral system in general and managing the process in particular. The purpose of this paper through a comparative analysis is to identify the elements that impede the observance of the fundamental constitutional principle of popular sovereignty either directly or indirectly through elected representatives to consolidate the rule oflaw in Albania.

Keywords: popular sovereignty, principle of democracy, constitution, separation of power, electoral system

\section{Introduction and a Brief Historical Presentation of the Principle of Sovereignty in Albania}

The selection of an electoral system to enable a fair representation of the people by the representative institution that is the parliament, which remains a process of continuous evolution in systems with consolidated democracy, no longer in a system with consolidating democracy as it is the case of the 
democracy in Albania. In fact, the need to find a suitable electoral system arises when this is dictated by the plurality of bids made from political entities which in fact creates what is necessary for the functionality of democracy, hence the political pluralism.

Since the creation of the Albanian state at the time of the proclamation of independence from the Ottoman Empire in 1912, the governing system of the state, political pluralism was introduced for the first time in 1921. It may be argued that it was the first time that in the governing system of Albania were presented alternatives, that essentially dictated a choice. The programs of these parties that presented themselves to run in the first pluralist elections, could be indicated as remarkably similar and were based mainly on the democratization of the society and above all on the economic progress of the country (Fischer, 1984, pp. 38-39). Nevertheless, was the Populist Party which included in its group predominantly intellectuals and patriots of the time, who had played significant role in the international camp for the defense of the Albanian cause to became a sovereign country (Puto, 2009, pp. 316-317). Other parties established in this first stage of the establishment of political pluralism were the Progressive Party and the Liberal Party during the Ottoman Era.

As introduced in the first phase of the formation of political pluralism in Albania and subsequently the guarantee of state sovereignty by the League of Nations, the aspiration to form a political party seemed actually more enthusiastic for the opportunities that power could provide rather than a mission in itself to contribute to the development of the country. These political parties, although created under the pattern of the parties of Western countries, do not seem to have succeeded in establishing a pluralistic political system worthy to empower as representatives of the sovereign, according to the principle of democracy.

This was the first time that a cooperation was established between the delegates and representatives in Albania, marking a competition to represent popular sovereignty through political pluralism. This experience was repeated in 1923 and afterwards accompanied by a political crisis. Since then political pluralism in Albania had fallen into "coma" for a long time. Nevertheless, strong political contradictions between the parties have been a differentiating element between them observing various disputes related to the modalities of the political elections' proceedings in Albania. (Kristo, 1920, p. 112).

In this context, it is obvious that governance in Albania is based on the tradition which has influenced the creation and the development of political pluralism in this country. This emphasizes that after the fall of communist regime in the Popular Republic of Albania as the Constitutions have entitled the government form, equal to the other countries of Central and South Eastern Europe which had embraced the same form of government and it deemed necessary to consolidate the popular sovereignty based on the governance alternatives.

These alternatives would define popular sovereignty, based in the political pluralism. This political pluralism, in absence of a previous tradition to enforce an important principle already sanctioned in the constitution of the Republic of Albania, such as the principle of popular sovereignty has not consolidated yet to respond to standards of a democratic electoral system.

\section{The Principle of Sovereignty According to the Constitution of the Republic of Albania and the Effective Implementation of this Principle}

In the Constitution of the Republic of Albania in Article 2 is sanctioned "Sovereignty in the Republic of Albania belongs to the people 2. The people exercise sovereignty through the representatives or directly (...) (Constitution of Albania, 1998, article 2). This basic principle for the implementation of the principle of democracy is applied based on the principle of governance through free, equal and periodic elections (Constitution of Albania, 1998, article 1). In order to conduct the elections, alternatives are needed among others shall be resolved, and these alternatives are created based on Article 9 of the Constitution which stipulates that "Political parties are easily created. Their organization must be in accordance with democratic principles (...)” (Constitution of Albania, 1998, article 9). In order to respect the principle of popular sovereignty, the subject of this study would be to apply the principles 
outlined above and providing its importance to this constitutional principle. Nevertheless, it seems that these principles have failed to ensure citizens participation and representation over every aspect of governance.

Thereby, since the first elections based on the political pluralism, Albania has been confronted with the fact of constant contestation of the principle of sovereignty by its representatives to those who enable the political pluralism.

Referring to the abovementioned, the Constitution of the Republic of Albania in paragraph 2 of Article 4 stipulates that, popular sovereignty is exercised either through elected representatives or direct representation. Regarding the second alternative, the popular sovereignty remains unimplemented in Albania and far from reality. In fact, the last time a referendum was held in Albania was in 1998 for the approval of the Constitution of the Republic of Albania'. For many years in Albania it has been deliberated about a reform and the way referendums are handled, even with the adoption of a special law, likewise the processing of this issue by the Constitutional Court of the Republic of Albania or the Venice Commission itself (Skëndaj, 2019, visited 23 July 2020).

Notwithstanding that in the Electoral Code, the law that regulates the referendums which are in continuous proposed amendments, and are mostly related to the general electoral process, the exercise of sovereignty through representatives and except for political discussions nothing has been done for a good regulation of exercising sovereignty appropriately. This, presumably due to the lack of political will to fully dimension the relationship with the representatives and thus a limitation of the principle of sovereignty which must pass through direct democracy. At this point it should be noted that direct democracy cannot replace democracy representative according to the contemporary concept of the democratic state, but to serve as its integral or complementary element (Bilancia, 2017, p. 2). Although the direct vote and expression of sovereignty in the Republic of Albania is foreseen in the Constitution, it remains impossible in implementation, notwithstanding the development of technology which seems to give an advantage to direct democracy over the representative democracy and it could be the online democracy (Bilancia, 2017, p. 2).

In addition to the approach of exercising sovereignty, democracy remains a great value and achievement of humankind. In such way, still today, as always, democracy constantly faces challenges and to uphold the values it represents at a time when not only Albania, but also the entire world is facing a challenge which is related to the constitutional rights to health, from the risk of corona virus spread, perhaps it is time to act in another direction since, the risk of this disease requires the avoidance of any kind of rallies, it seems to be the time to defend democracy even the representative one, through the electronic voting system (Clementi, 2020). The practice of the latter probably would serve to the development of democracy through exercising the constitutional principle of sovereignty directly as an essential element of the concept of democracy in general.

Stressing the need to representative democracy, instead of exercising direct sovereignty the Albanian legislator needs to carry out changes in this regard.

As abovementioned, the lack of special legislation on referendums seems to have limited the active participation of the people in the contribution it can make to the consolidation of democratic values, although this form may be an alternative rather than a choice. Thus the 2008 electoral code repealed from the electoral code in 2003, in Article 185 decided that the part nine of that code relating to referendums would remain in force until the adoption of a special law on referendums (Law No. 10 019, dated 29.12.2008 (amended by law no. 74/2012). Article 185) ${ }^{2}$. However, as noted in the Electoral Code of the Republic of Albania itself, the law that has been amended and further amendments have

${ }^{1}$ The approval of the Constitution of the Republic of Albania by referendum dated on 22.11.1998.

${ }^{2}$ Please see Article 185 of Law No. 10 o19, dated 29.12.2008 (amended by law no. 74/2012). This law is in its proposal to be amended and most probably preceded by constitutional amendments, after collaboration with the two Albanian oppositions, the one in parliament and outside parliament with the ruling majority as always under the supervision of the representatives of the United States of America and the European Union. 
been proposed in terms of electoral process on the representative democracy and the direct participation, since then the Albanian legislator has not introduced any approach in enacting coherent and at the same time effective legislation.

The law on popular referendums, in fact, should apply the principle of popular sovereignty by notifying the latter to decide on certain issues certainly within the limits of constitutional agreement. In view of Article $151^{3}$, point 2 of the Constitution of the Republic of Albania is foreseen the issues for which cannot be held referendums, so this constitutional regulation that the sovereign itself had approved in the referendum related to the approval of the constitution in 2008 , should have promoted the function of the legislator for a special agreement for the exercise of direct sovereignty.

Nevertheless, the abovementioned electoral code makes it absolutely impossible to exercise popular sovereignty, although initiatives to undertake such an activity never lacked from the part of the sovereign ((Skëndaj, 2019, visited 23 July 2020). The latter has been subject to provisions which through sovereignty exercised by the representatives have rendered the constitutional provision which foresees direct sovereignty as a formal constitutional provision.

Certainly, in order to respect the principle of democracy, the enforcement takes into the constitutional principle of popular sovereignty through the representatives of the sovereign. It was underlined above that representative authority since the establishment of political pluralism has put this provision as a slogan of political power, in the meaning of a challenge of the latter to achieve this, considering being an impossible mission. In this context, it is worth emphasizing how much the concept of popular sovereignty stands and is treated as a political ideology (Schmit, 1972, p. 34).

The Constitution of the Republic of Albania, approved by an indisputable majority in 1998, and sealed through the last popular referendum held in the Republic of Albania until today, provided that the Albanian parliament consisted of 140 deputies. These were elected through an electoral system which consisted of 100 constituencies and then in order not to distort popular sovereignty was corrected by 40 parliamentary positions through the proportional system.

Arguing that there is no electoral system that perfectly reflects popular sovereignty through elections, it was by coincidence to put into question the recognition of sovereignty through this system. This turned the principle of sovereignty into the cornerstone of the challenge among the representatives of the people, which was intended to ensure that the election results were not contested. But the contrary appears to have happened in practice, which means that the elections are contested. In this respect, it is worth noting that the proceedings to express political decisions, though indispensable, may not be sufficient as a reference for today's constitutional democracies having the same notion of political democracy to define democracy (Ferreajoli, 2012, p.79). This is not just history, but the truth does nothing but question the principle of popular sovereignty.

Consequently, in 2008 in the new constitution of the Republic of Albania, was considered reasonable by the main representatives of the sovereign to make changes that would improve the electoral system. Thus, from the majority-proportional system was switched to the proportional system, maintaining the same number of members of parliament, 140 whom represent popular sovereignty as defined in Article 64 of the Constitution (Law no. 9904, dated 21.04.2008) ${ }^{4}$. Regarding the characteristics of this system, we can go back to the general principle that up to date has not introduced an electoral system to utterly exercise the principle of sovereignty.

Though this electoral system likewise as the abovementioned is not an Albanian disclosure, which

${ }^{3}$ Article 151 point 2 of the Constitution of the Republic of Albania "Issues related to the territorial integrity of the Republic of Albania, the restriction of fundamental human rights and freedoms, the budget, taxes and financial obligations of the state, the establishment and annulment of the state of emergency, the declaration of war and peace and the amnesty, they cannot be subject to any referendum."

${ }^{4}$ Article 64 of the Constitution amended by law no. 9904, dated 21.04.2008 "1. The Assembly consists of 140 deputies, elected by a proportional system by multi name constituencies. 2. The multi name constituency is in compliance to the administrative division to one of the levels of administrative-territorial organization.3 (...). " 
ultimately is recent and new experience to the electoral systems, but it is a system that has been applied in other countries, and that can more easily create stability through the creation of a governing majority. Although the political decision-making shall constitute the popular representation, sovereignty through general elections, we can understand that the principle of majority guarantees only the democratic form of the election of representatives, but this doesn't imply that the decisionmaking power based on the majority have equal values as justice (Ferreajoli, 2012, p.73).

The concept of sovereignty needs to be sorted out in a way to definitely establish and effectively address the enquiries arising related to the consensus of collective social impact over territory, perhaps even against positive law, and to impose this decision to all citizens in the country, defining sovereignty as an end to the conflict of interest. (Morrone, 2017, p. 67).

In any case, the electoral system to establish the principle of popular sovereignty cannot be divided from a socio-political context of a country, and it can be said that it is indisputable related to the pluralistic tradition that a state could provide.

The proportional electoral system was established and accepted widely by the political actors, and was ratified in the Constitution of 2008 , for the fact that the representatives of the parties representing the majority of the sovereign gave their support. The only objections related to the alternatives of the political pluralism that had not quite importance to sovereignty were opposed with the argument that parts of the sovereign would be unrepresented.

The constitutional amendments in the way the principle of popular sovereignty was exercised required adjustment in the law which serves to carry out the electoral system. Although the constitutional adjustments of 2008 in the Constitution of Albania did not only affect the provisions which were related to the electoral system and arguably, they are not unusual in the 22-years of Albanian Constitution. The Electoral Code is the law to which adjustments are requested and undertaken after each electoral process. Over the latter, it appears the necessity to overpower with or without arguments the problems encountered in the electoral process above all from the alternative of political pluralism which fails to be the majority of state power.

The proportional system chosen by the Albanian lawmaker was based on regional division. Thus, the constituencies are located on the basis of 12 districts which serve as administrative-territorial divisions in the Republic of Albania, there are created the lists of candidates based on the number of seats assigned to each district in proportion to the number of population while taking into account the constituencies (Law No. 10 019, dated 29.12.2008 (amended by law no. 74/2012). It is worthy to emphasize that in a country with weak/fragile democracy such as Albania, cannot be presumptive claim of an internal democracy of political parties. In such way, the lists of candidates to represent popular sovereignty remain the prerogative of the chairman of the political party, although it has often been manifested that these lists are set up on the basis of internal elections. But, in order to preserve and save democracy, it is necessary that those who make decisions must do so in defense of democracy itself (Zakaria, 2003, p. 317).

\section{Albania in Seeking of Popular Sovereignty in Addition to be Submitted its Membership in the European Union}

In the European Union, the notion of the principle of sovereignty seems far from that constitutional principle provided by the Constitution of Albania. In fact, the organization of the European Union bases its existence on the sovereignty that the member states have granted to this organization by relying on joint governing institutions which adopt legal norms applicable to the member states. In this way, from the creation of the European Union and onwards, most researchers of law and politics have come to believe that state sovereignty had given way to European sovereignty as a more appropriate form to meet the contemporary challenges that are related to the economy, social policies more feasible at the European level (Valia, 2016, p.85).

As one of the priorities of political pluralism in Albania, is accurately the country's membership in the European Union, this pluralism in this context turns into a common option of all political forces. 
This is indisputably dictated by the free will of the Albanian sovereign, who sees as feasible the principle of constitutional sovereignty in a possible Albanian membership in this organization. In this context it is worth mentioning a more secular explanation of sovereignty in the sense that this sequence is required to those who are subjects to power because sole sovereign is able to ensure their integrity (Bin, 2013, pp. 371-372).

Furthermore, one of the criteria that this organization seeks for potential candidate countries, such as the case of Albania, is the effective realization of the constitutional right of the sovereign to elect its representatives. Though Albania is not a member state of the European Union in terms of constitutional and legal reforms which have aimed to implement the right to vote, they have been supported not to say that they were initiated by the representative of the European Union in cooperation with the representative of the United States of America in this country. This process is based on the continuous assistance provided by the European Union to strengthen the consolidation of the rule of law in Albania and the constitutional principles that implement this principle with the aim of the country's membership in this organization. Despite the fact of not referring directly to Albania and referring to Italy while stressing that it applies equally to this country, the demand and the idea of a democratic and representative Republic in the process of European integration for all citizens and researchers implies as a civil as well as cultural challenge that should be appreciated (Morrone, 2018, p. 15).

In this regard, depending on the case of the representatives of the European Union, in function of political stability in Albania, have been able or have tried to minimize certain elements that have put into question the exercise of popular sovereignty through the right to choose to be enforced by the latter.

In any case, different perspectives in the representation of the European Union as mentioned above have pointed out the deficiencies which have influenced the taking of further steps in the long progress of integration of Albania in this organization. This is noted in the last case when the French President at the meeting of the European Council in October 2019 decided to adjourn the opening of negotiations for Albania and Northern Macedonia.

Although the main point that did not enable the development of this process was not only the issue related to the electoral process as the main phenomenon that marks the enforcement of the constitutional principle of popular sovereignty, this was also endorsed by the German parliament. Indeed, though the German representative to the European Council was in favor of starting the negotiations for two of the Western Balkan countries in a voting election in the German Parliament, the issue of contesting the regulation of the right to vote was a request that the latter led to Albania to remedy this issue.

However, the Albanian opposition, referring to some wiretaps that supported the request, the idea of compromising the determination of the sovereign for a long time has sought free, equal and fair elections and in the present case, this was never taken into account by the lead of political power. Otherwise, in response to the decision-making by the European Council, the Prime Minister of the Republic of Northern Macedonia announced instant elections to reaffirm to the sovereign the principle of popular sovereignty of holding the power of governance. Undoubtedly, the subject of this analysis is not the political opinion but the processing of aspects that are closely related to the exercise of the principle of popular sovereignty in the Republic of Albania.

Albanian political pluralism on which the principle of popular sovereignty should be based through representation, the untimely return to the sovereign has been a rare and sometimes extremely dictated process. Perhaps in this case as an extreme and necessary element it may be considered the undisputed desire of the sovereign to be part of European citizenship, as provided for in the agreements of the European Union for the citizens of the member states. Yes, democracy is not an organizing pattern because whether we could express this point of view, we could not recognize any democratic deficit, to the European Union itself (Bin, 2014, p. 4). 


\section{Albanian Parliament among the Need to Execute Instant Elections, Successive Adjustments in Electoral System and Respect for the Principle of Popular Sovereignty}

The year 2020 marks the 1ooth anniversary of the establishment of the Albanian parliament. This 1ooth anniversary cannot mark a celebration to the Albanian parliament due to this jubilee. It is however noticed that influences and interceptions of the members of the ruling party in the country have been involved in distorting the electoral process and consequently the sovereignty. This distortion of the sovereignty will can be nothing but the demolishment of the principle of popular sovereignty. The bottom line, through popular sovereignty has been shifted a crucial and disfigured concept of constitutional theory, that of constitution-making (Bin, 2013, p. 372).

Thus in 2019, as never before in its 100-year history, unprecedently the parliament was uncompleted in number of its representatives. The electoral system through multi-name lists had made it possible the replacement by descendants following the order of the lists although most of the names that made up the lists had remained under the accountability view to the political will of the political representatives.

Representatives of a part of the sovereign that constituted the political opposition in parliaments had withdrawn from the tenure that the representatives had given in the 2017 during the parliamentary elections. The 2017 parliamentary elections were held after a period of protests by part of this opposition, which was apprehensive before the distorted notion of the principle of sovereignty by the government by using pressure on public administration. As a guarantee for the regularity of the election process, they had found a solution which consisted in the possibility of participation of opposition representatives in the government cabinet as well as in important positions of public administration. However, the so-called solution to guarantee the electoral process, like any settlement to Albanian political pluralism to ensure the principle of popular sovereignty, had come up as a result of American international binding arbitration and the European Union, where the core remained Albanian political "monism-as the only doctrine to one governing party at the time" dictated by the sovereign, Albania's membership in the European Union.

In this framework, were held the elections of 2017, whereby, as above indicated, due to some verbal influences of political actors indirectly related to the election process raised the questions of its regularity, we had come into conclusions of what was the inducement a problem of the 100-year history of the Albanian parliament. It is worth mentioning that during the whole history of Albanian political pluralism, the electoral processes were contested and consisted of continuous boycotts, regardless of who was the current political opposition, but cessation of tenure was a new and unknown concept. Thus, this 1ooth anniversary of the Albanian parliament, not celebrated due to the pandemic situation of COVID-19 spread, but even without unjustifiable reason, it can hardly be considered a celebration to occur.

Though the opposition's demand for instant elections remained, in January 2020, what is considered the international component had made it possible to sit in discussion of sovereign representatives in order to conduct the next process of the electoral reforms. In this regard, there were discussion among the majority and two oppositions. The opposition both inside and outside the parliament, which in presenting the termination tenure in Parliament terms, were faced with a new responsibility, that of representing its part of the sovereign.

There are different views on the constitutional legitimacy of the Parliament due to the fact that even though some vacancies left by the opposition that had presented their tenure were replaced by the successors of the electoral lists, it still failed to reach the number of 140 deputies as provided in the constitution. This raised the question of the legitimacy of the outcome of the reform as to how it would be achieved to receive the necessary support for approval. Hence, the mediators of the conduct of the reform process settled a condition that the legal or constitutional draft that would be the result of these negotiations had to be approved by the parliament without adjustments. This raises some questions about the significant role of Parliament and its legitimacy but above all constitutional decision-making must be based on parliamentary debate instead, or are we facing a parliamentary potential crisis 
(Psquino-Pelizzo, 2006, p. 15).

This is the way the next reform of the electoral system finds the representative of the sovereign. Probably because sovereignty is a quality of the legal disposition or its values without which the legal disposition itself would be worthless (Morrone, 2017, p. 68).

Although when engaged in these discussions, there was necessary to intervene solely in terms of activity of electoral code to avoid such frequent constitutional amendments to the Albanian basic law, also in this case it seems that it was decided to amend the provisions of the Constitution (Constitution of Albania, 1998, article 64)5. Whilst the so-called parliamentary opposition was required to amend the system based on open lists, this was not achieved. Perhaps, the obstacle for the open lists must have been the authority of the main political representatives who in this way would lose the sole right of appointing the candidates and consequently would lose the oppressive and power that the Albanian political pluralism has dictated to the party leaders.

\section{Conclusions}

The Constitution of the Republic of Albania has foreseen the principle of popular sovereignty for the functioning of democracy and the rule of law. In almost 30 years of political pluralism in Albania which should normally serve to reflect the diversity of the sovereign will, Albania remains in search of this principle. One of the main reasons why Albania shall fulfill this principle is the fact that it constitutes an important and crucial condition for its membership in the European Union. Regardless the fact that the latter has consistently supported this common need of Albania and the European Union, it remains an impossible mission to implement the principle of popular sovereignty. Though the Republic of Albania has undertaken continuous reforms to implement the constitutional right to vote and to be elected, the lack of a pluralistic political culture has always made these processes contestable by the next opposition. Reforms in this regard have not only referred to the electoral law but also to the Constitution, depreciating the later every time it is interceded. In this context, a significant role should be performed by the European Union due to the fact that in all these years only its intercession has enabled the implementation of the principle of popular sovereignty. As noted, adjustments in electoral systems have prevented to implement the principle of sovereignty of the people. The principle of the sovereignty, more than a constitutional principle that guarantees country's functionality, prior to delegate the power to the European Union upon integration into the union has served as a slogan of political parties.

The latter seem to serve more than the principle of popular sovereignty providing the opportunity to increase their political force in order to retain State Power. This has also been pointed out in the fact that important part of the principle of popular sovereignty related to its enforcement within the limitations of the constitutional provisions has never been fulfilled since the constitution was adopted in 1998. Although there have been initiatives to implement direct sovereignty, the lack of a legal framework to promote this process has been an obstacle. Consequently, the political will has to guarantee direct popular sovereignty by adopting a law which would periodically constitute the enforcement of this constitutional principle. This most likely will resolve many of the political gaps that lead the Albanian governance in these years of political pluralism and considerably will fade the distance between the representatives and the represented citizens. Thus, in achieving the intended objectives of Albania's membership in the European Union, Albanian citizens would be represented as European citizens buy their country, as well as European Union itself. In this context, the European Union will have to intervene constantly to defuse the political tension in Albania in name of guaranteeing the implementation of the principle of sovereignty.

\footnotetext{
${ }^{5}$ It is speculated to amendments in Article 64 the Constitution in order to prevent pre-election coalitions. Other amendments are also being argued but by the end of the reform approval, the experience of Albanian politics indicates that issues that seem so difficult to accomplish are often easily to be performed by independent terms.
} 


\section{References}

Bilancia P., (2017). Democrazia diretta vs Democrazia rappresentativa Profili problematici nel costituzionalismo contemporaneo, in Federlismi.it, codified number 1/2017, p. 2.

Bin R., (2013). La sovranità nazionale e la sua erosione, in Per una consapevole cultura costituzionale. Lezioni magistrali, (a cura di) Andrea Pugiotto, Napoli, p. 371-372.

Bin R., (2014). Nuove strategie per lo sviluppo democratico e l'integrazione politica in Europa: Relazione finale, in AICRivista n. 3/2014, p.4.

Clementi F., (2020) Proteggere la democrazia rappresentativa tramite il voto elettronico: problemi, esperienze e prospettive (anche nel tempo del coronavirus). Una prima introduzione, in Federlismi.it, n.6/2020, 18 marzo 2020.

Constitutional Law No. 9904, dated 21.04.2008, titled: "On some Changes" in the law No. 8417 dated 21.10.1998 "Constitution o Republic of Albania" changed.

Ferrajoli L., (12). La democrazia costituzionale (Constitutional Democracy), in Revus Journal for Constitutional Theory and Philosophy of Law / Revija za ustavno teorijo in filozofijo prava, 18/12, p. 79.

Fischer J. B., (1984). King Zog and the struggle for stability in Albania, Columbia University Press, U.S.A., 1984, trans. al. Hajderi K., pp. 38-39.

Floqi K., (1920). E Drejta Themelore, Shkodër, p. 112.

Law No. 8417 dated 21.10.1998 "Constitution o Republic of Albania" amended, article 2, 1, 9, 64.

Morrone A., (2017). Sovranità, in AIC-Rivista, n. 3/2017, p. 67.

Morrone A., (2018). Governo di cambiamento, in Federalismi.it, n. 12/2018, p. 15.

Law No. 10 019, dated 29.12.2008 (amended by law no. 74/2012) "Election Code of the Republic of Albania".

Schmitt C., (1972) Le categorie del «politico», Il mulino, Bologna, p. 34 and onwards.

Skëndaj E. (2019), Historiku i referendumeve në Shqipëri, in https://ahc.org.al/historiku-i-referendumeve-neShqiperi/, date of entry in power, 23/07/2020.

Pasquino G., Pelizzo L., (2006). Parlamenti democratici, Bologna, il Mulino, p. 15.

Puto A., (2009). Shqipëria Politike 1912-1939, Toena, Tiranë, pp. 316-317.

Valia I., (2016). Sovranità e diritti umani, in Tigor: rivista di scienze della comunicazione e di argomentazione giuridica - A.VIII (2016) n. 1, p. 85.

Zakaria F., (2003). The Future of Freedom. Illiberal Democracy at Home and Abroad, tr. it. Democrazia senza libertà in America e nel resto del mondo), Milano, p. 317. 